\title{
Modifiable Risk of Breast Cancer in Northeast Iran: Hope for the Future. A Case-Control Study
}

\author{
Mohammad R. Motie ${ }^{a}$ Sima Besharat ${ }^{b}$ Reza Torkjazic ${ }^{c}$ Mahdieh Shojaa ${ }^{c} \quad$ Mahsa Besharat $^{c}$ \\ Abbasali Keshtkar ${ }^{c}$ Gholamreza Roshandel ${ }^{c}$ Saba Besharat ${ }^{d} \quad$ Fateme Arab Ameri $^{\mathrm{c}}$ \\ aSurgical Oncology Research Center, Imam Reza Hospital, Faculty of Medicine, Mashhad University of Medical Sciences, Mashhad, \\ ${ }^{b}$ Golestan Research Center of Gastroenterology and Hepatology, Golestan University of Medical Sciences, Gorgan City, \\ ${ }^{\circ}$ Golestan University of Medical Sciences, Gorgan City, \\ ${ }^{\mathrm{d}}$ Tehran University of Medical Sciences, Tehran, Iran
}

\section{Keywords}

Breast cancer - Risk factors - Golestan .

Case-control study

\section{Summary}

Background: Breast cancer is the most common cancer in women. Its prevalence is increasing annually by $2 \%$. The determination of modifiable risk factors has been the subject of various studies. The aim of this study was to determine risk factors of breast cancer in women in Golestan Province. Patients and Methods: This case-control study was conducted among women with breast cancer recorded in the cancer registry system between 2004 and 2006 ( $n=134$ ), and their age-matched healthy neighbors ( $n=133$ ). Data were statistically analyzed. Results: Age at marriage, menarche and pregnancy, breast feeding, positive family history, marital status, and educational level were not significantly correlated with risk of breast cancer, but age at menopause $1<46.6$ years) was significantly correlated $(95 \%$ confidence interval 1.15-7.37; $p=0.021)$. Live births, still births, and infant deaths were not significantly different between the 2 groups. For other variables, such as smoking history, no odds ratio was calculated. Conclusion: Results show that there is no significant correlation between variables and risk of breast cancer in our population, except for age at menopause. A large cohort study is recommended.

\author{
Schlüsselwörter \\ Mammakarzinom · Risikofaktoren · Golestan . \\ Fallkontrollstudie
}

\section{Zusammenfassung}

Hintergrund: Das Mammakarzinom ist die häufigste Krebsart bei Frauen mit einer jährlichen Prävalenzzunahme von $2 \%$. Verschiedene Studien haben sich mit der Bestimmung modifizierbarer Risikofaktoren befasst. Ziel der vorliegenden Studie war es, Brustkrebs-Risikofaktoren bei Frauen in der Golestan-Provinz zu bestimmen. Patienten und Methoden: Diese Fallkontrollstudie wurde mit Brustkrebspatientinnen, die zwischen 2004 und 2006 im Krebsregister aufgenommen worden waren ( $n=134$ ) sowie deren altersentsprechenden Nachbarn ( $n=133$ ) durchgeführt. Die Daten wurden statistisch analysiert. Ergebnisse: Weder das Alter zum Zeitpunkt der Heirat, Menarche und Schwangerschaft, das Stillverhalten, eine positive Familienvorgeschichte, der Ehestand noch der Bildungsstand waren signifikant mit dem Brustkrebsrisiko korreliert. Das Alter bei Einsatz der Menopause $(<46,6$ Jahre) war dagegen signifikant korreliert (95\% Konfidenzinterval 1,15-7,37; $p=0,021$ ). Bei Lebendgeburten, Totgeburten und Kindstod bestanden keine signifikanten Unterschiede zwischen den beiden Gruppen. Für andere Variablen wie beispielsweise dem Raucherstatus wurde keine Odds-Ratio berechnet. Schlussfolgerung: Die Ergebnisse zeigen, dass keine signifikante Korrelation zwischen den Variablen und dem Brustkrebsrisiko in der von uns untersuchten Population besteht. Die einzige Ausnahme bildet das Alter bei Einsatz der Menopause. Eine größere Kohortenstudie ist empfehlenswert.

\section{KARGER \\ Fax +497614520714 \\ Information@Karger.de}

www.karger.com (c) 2011 S. Karger GmbH, Freiburg

$1661-3791 / 11 / 0066-0453 \$ 38.00 / 0$

Accessible online at:

www.karger.com/brc 


\section{Introduction}

Breast cancer is the most prevalent cancer in women worldwide, with an annual increase in prevalence of about $2 \%$. In 2000 , the breast cancer incidence increased to 1 in 8 women. In the 7th decade of life, it will affect 1 in 13 American women, and in the 8 th decade 1 in 11 women $[1,2]$. There are significant variations between geographic areas with regard to breast cancer incidence [3]. Over the next decade, as women adapt to western lifestyles by marrying and bearing children later in life, developing countries may face a potential breast cancer epidemic [3], and due to these lifestyle changes and the lack of resources to create mass awareness and provide early detection, the incidence is increasing across countries with lower health care facilities. Iran is amongst the medium prevalence countries, but its incidence and prevalence are increasing [4]. Similar to other developing countries, the mean agespecific incidence of patients in Iran is 10-20 years less than other countries (approximately 47 years) [5]. Iran is estimated to face a serious breast cancer burden in the coming years.

As the Golestan cancer registry shows, breast cancer is the 3rd most common cancer in our province, after esophageal and stomach cancers, with an age standardized rate of 13.5 per 100,000 [6]. Considering the incidence and prevalence of breast cancer, the high cost of treatment, and the young age at disease onset, it is important to urge governments to aggressively schedule strategies for early detection such as providing mammography machines in health care facilities and hospitals $[3,7]$. Several risk factors are considered for breast cancer some of which are confirmed, while others are controversial and may be rejected. In Iran, few studies about breast cancer risk factors exist. This study was designed to detect the risk factors for the Golestan Province, Northeast Iran.

\section{Patients and Methods}

This case-control study included all patients who were registered as having breast cancer between 2004 and 2006. Age-matched neighbors were used as controls. Names and addresses were derived from the cancer registry system of Golestan Province. The database contained 300 registered cases some of which were repeated and therefore deleted from the list, some addresses were incomplete, and others had moved to a different location, leaving a total of 134 cases. The population-based cancer registry gathers data relating to cancer patients of all pathologies from laboratories, hospitals, local health offices, clinics, and physician offices. However, despite strong recommendations by the coordinator, personnel who fill in the forms frequently fail to write down a complete and straight forward home address, which causes limitations for our kind of study. Furthermore, due to the lack of community-wide screening programs and no specific attention being paid to routine simple screening tests, patients are usually referred at high stages of cancer. We used trained personnel from the Golestan Health Network to complete valid and reliable questionnaires through interview. Patients who had passed away were excluded and no control was considered for them. One supervisor controlled all questionnaires of a particular district and posted the completed forms to the main office of the Health Deputy. The questionnaire included demo- graphic data such as age, residency, ethnicity, marital status, profession, educational level, and risk factors which were discussed in previous studies such as age at menarche, menopause and first pregnancy, number of children, and number of abortions. The coded data were entered into a computer and analyzed using SPSS-13 (SPSS Inc., Chicago, IL, USA); statistical tests included chi square and independent t-test as well as nonparametric tests; $95 \%$ confidence interval and odds ratio (OR) were calculated.

\section{Results}

Of the registered cases, 52 were dead and 162 could not be found for various reasons; 134 cases and 133 controls were enrolled. The mean age was $47.15 \pm 10.36$ years (cases) and 42.96 \pm 11.93 years (controls). All demographic data and risk factors addressed in the questionnaire are reported in table 1. Those factors which had a $p$ value of less than 0.2 were in-

Table 1. Distribution of demographic data and risk factors in breast cancer cases and controls

\begin{tabular}{|c|c|c|c|}
\hline & Cases, n (\%) & $\begin{array}{l}\text { Controls, } \mathrm{n} \\
(\%)\end{array}$ & $\mathrm{p}$ \\
\hline Residence & & & 0.896 \\
\hline Urban & $81(63.77)$ & $82(64.56)$ & \\
\hline Rural & $46(36.22)$ & $45(35.43)$ & \\
\hline Total & $127(100)$ & $127(100)$ & \\
\hline Ethnicity & & & 0.636 \\
\hline Turkmen & $31(27.19)$ & $31(30.09)$ & \\
\hline Fars & $83(72.8)$ & $72(69.9)$ & \\
\hline Total & $114(100)$ & $103(100)$ & \\
\hline Marriage & & & 0.702 \\
\hline Single & $4(3.14)$ & $3(2.36)$ & \\
\hline Married & $123(96.85)$ & $124(97.63)$ & \\
\hline Total & $127(100)$ & $127(100)$ & \\
\hline Professional status & & & 0.719 \\
\hline Housewife & $108(85.03)$ & $110(86.61)$ & \\
\hline Professional & $19(14.96)$ & $17(13.38)$ & \\
\hline Total & $127(100)$ & $127(100)$ & \\
\hline Educational level & & & 0.594 \\
\hline Illiterate & $101(79.5)$ & $97(76.37)$ & \\
\hline Educated & $26(20.47)$ & $30(23.62)$ & \\
\hline Total & $127(100)$ & $127(100)$ & \\
\hline Contraception & & & 0.163 \\
\hline Oral contraceptives & $47(50.53)$ & $41(36.28)$ & \\
\hline Other & $46(49.46)$ & $72(63.71)$ & \\
\hline Total & $93(100)$ & $113(100)$ & \\
\hline History of infertility & 18 & 8 & 0.03 \\
\hline History of abortion & 38 & 38 & 0.78 \\
\hline History of stillbirth & 10 & 6 & 0.27 \\
\hline $\begin{array}{l}\text { Hormone replacement } \\
\text { therapy }\end{array}$ & 1 & 3 & 0.34 \\
\hline $\begin{array}{l}\text { History of cancer in } \\
\text { first-degree relatives }\end{array}$ & 23 & 12 & 0.04 \\
\hline $\begin{array}{l}\text { History of cancer in } \\
\text { second-degree relatives }\end{array}$ & 13 & 9 & 0.37 \\
\hline $\begin{array}{l}\text { History of cancer in the } \\
\text { patient her/himself }\end{array}$ & 10 & 0 & 0.002 \\
\hline $\begin{array}{l}\text { History of benign lesions } \\
\text { in the breast }\end{array}$ & 9 & 2 & 0.06 \\
\hline $\begin{array}{l}\text { History of radiation to } \\
\text { head/neck and chest }\end{array}$ & 22 & 4 & 0.78 \\
\hline
\end{tabular}




\begin{tabular}{lll}
\hline & $\begin{array}{l}\text { Univariate analysis, } \\
\text { crude OR (CI 95\%) }\end{array}$ & $\begin{array}{l}\text { Multivariate } \\
\text { analysis, adjusted } \\
\text { OR (CI 95\%) }\end{array}$ \\
\hline History of infertility & $2.54(1.06-6.08)$ & $0.48(0.1-2.29)$ \\
History of cancer in first-degree relatives & $2.12(1.01-4.47)$ & $1.07(0.22-5.24)$ \\
History of other cancers in the patient her/himself & $1.09(1.03-1.14)$ & $0(0.00-0.00)$ \\
History of benign lesion in the breast & $4.73(1.01-22.34)$ & $0(0.00-0.00)$ \\
History of radiotherapy to head/neck and chest & $6.39(2.14-19.17)$ & $0.13(0.01-1.26)$ \\
Age at marriage & $1.07(1.01-1.13)$ & $1.17(1.03-1.33)$ \\
Age at menopause & $0.92(0.84-0.99)$ & $0.92(0.84-1.01)$ \\
\hline CI = Confidence interval. & & \\
\hline
\end{tabular}

Table 2. Odds ratio (OR) of different risk factors by univariate and multivariate regression analysis
Table 3. Comparison between cases and controls regarding age at marriage, menarche, menopause, and first pregnancy

\begin{tabular}{llll}
\hline & Cases, mean \pm SD & $\begin{array}{l}\text { Controls, } \\
\text { mean } \pm \text { SD }\end{array}$ & $\mathrm{p}$ \\
\hline Age at marriage & $20.12 \pm 5.11$ & $18.45 \pm 4.49$ & 0.006 \\
Age at menarche & $13.13 \pm 1.24$ & $13.42 \pm 1.42$ & 0.593 \\
Age at menopause & $45.81 \pm 6.04$ & $48.31 \pm 4.56$ & 0.04 \\
Age at first pregnancy & $21.07 \pm 5.02$ & $21.56 \pm 18.61$ & 0.77 \\
\hline SD $=$ Standard deviation. & & & \\
\hline
\end{tabular}

cluded into the regression analysis. As shown in table 2, after univariate and multivariate regression analysis, the most important risk factor associated with risk of breast cancer was age at marriage. The mean age at marriage was significantly higher in cases than in controls, in both univariate and multivariate analysis. The mean age at menarche was not significantly different between cases and controls $(\mathrm{p}=0.593)$ (table 3). Results indicate that the mean age at menopause was less in the case group than in the control group $(p=0.04)$, but in multivariate analysis no significant relationship was seen. Mean age at first pregnancy was not significantly different between cases and controls (table 3$)(p=0.77)$. No difference was seen between the 2 groups with regard to live births, live children, history of still births, and death of children aged $<2$ years $(\mathrm{p}>0.05)$. No significant correlation was seen between the risk of breast cancer and marriage status $(\mathrm{p}=0.702)$, educational level less than diploma $(\mathrm{p}=0.594)$, history of breast cancer in second-degree relatives $(p=0.37)$, and breast feeding. ORs were not calculated for smoking and other diseases due to the low amount of positive cases.

\section{Discussion}

Results show that the mean age of patients was $47.15 \pm 10.36$ years, which is very similar to other studies in Iran and other countries [8-13]. In our study, there was no significant correlation between age at marriage and risk of breast cancer. In another study carried out in Shiraz, a significant rise in the risk of breast cancer was seen when marriage occurred after 25 years of age [14]. Maybe sexual activity and its effect on sex hormone secretion play a role here. In the present study, significant correlation was seen between breast cancer and menarche occurring before 13.37 years of age and menopause before 46.6 years of age $[8,14]$. However, another study showed an $\mathrm{OR}=0.72$ for menarche after 17 years of age [15], and others even showed a protective role of late-age menarche [16]. It has been said that a lower age at menarche and a higher age at menopause can influence the risk of developing breast cancer $[17,18]$. Maybe the fact that hormone replacement therapy is not used in our area plays a role in the present results $[2,19]$. The results also show an increase in the risk of breast cancer in women who deliver their first child at age less than 20.51 years (not significant). Numerous studies indicated that age at first delivery can be a risk factor $[8,14$, $16,17,20]$. Also, nulliparity and the total number of children have been reported as risk factors [17, 21, 22] but we did not find this in the present study. Others showed a protective effect of parity and breast feeding with a $7 \%$ decrease in breast cancer risk seen for every 12 months of breast feeding [15]. In the present study, breastfeeding for a total of $>64.35$ months had an $\mathrm{OR}=0.73$. A protective effect of breastfeeding was reported before [22-25, 15, 18], although others reported no protective effect [26]. In our area, no significant correlation was seen between risk of breast cancer and marriage. This was similar to other studies [20,14,27], but some authors have reported a higher risk for married women [10]. Some interfering variables like oral contraceptives can be included here. No significant relationship was seen with regard to lower educational levels and family history of breast cancer, but the latter was reported to be a risk factor in other reports $[8,9,18]$. Here, we only saw a significant correlation between risk of breast cancer and lower age at menopause (which was not confirmed in multivariate analysis).

Breast cancer development is a multifactorial process which includes a complex interaction between physical activity, diet, energy intake, and body weight. This suggests that continual updating of knowledge on primary prevention and identification of behavioral changes will reduce the risk [23]. Thus, prevention strategies in our area could include avoidance of modifiable risk factors such as late first pregnancy, absence or short duration of breast feeding, and use of hormone replacement therapy in postmenopausal women which is encouraged in some studies. Our findings have highlighted the heterogeneity of breast cancer etiology across populations and indicated the need for further studies. The most interest- 
ing result of this study was the significant correlation between age at marriage and risk of breast cancer, which could be a modifiable risk factor, especially in our area. Also, treatment of infertility, planning for earlier detection of cancer in those with a positive history of breast cancer in first-degree relatives or in persons with a medical history of other cancers or benign lesions of the breast could be modifiable risk factors applicable for this area and potentially helpful in the quest to change the pattern of breast cancer.

\section{Acknowledgement}

The authors thank all colleagues in the health care facilities of Golestan Province who helped gather data, and the Deputy of Research at Golestan University of Medical Sciences who funded the project.

\section{Disclosure Statement}

There was no conflict of interest.

\section{References}

1 Bland KI, Beenken SW, Copeland EM 3rd: The breast; in Brunicadi F, Anderson D, Billiar T, Dunn D, Hunter J (eds): Schwartz's Principles of Surgery, 8th ed. New York, NY, McGraw-Hill, 2005, pp. 453-503.

2 Rochefort H, Rouëssé J; Groupe de Travail de la Commission III (Cancérologie): How to reduce the incidence of breast cancer. Bull Acad Natl Med 2008;192:161-79.

3 Bagchi S: Breast cancer rises in India. CMAJ 2008;179:27.

4 Abolhassani F, Khayamzadeh M, Moradi Lake M, Jamali A, Salmanian R, Naghavi M: Estimation of breast cancer burden in Iran in 2003 and its comparison with Eastern Mediterranean region and the World in 2002. Payesh (Journal of The Iranian Institute For Health Sciences Research) 2007;3:233-41.

5 Ursin G, Spicer DV, Bernstein L: Breast cancer epidemiology, treatment and prevention; in Goldman MB, Hatch MC (eds): Women and Health, 1st ed. New York, NY, Academic Press, pp. 871-81.

6 Semnani S, Roshandel G, Keshtkar A, Sadjadi A, Moradi A, Nouraie SM, et al.: Annual Report of the Golestan Population-Based Cancer Registry (GPCR), no. 3. Gorgan, Peik Reyhan, 2008.

7 Madigan MP, Ziegler RG, Benichou J, ByrneC, Hoover RN: Proportion of breast cancer cases in the United States explained by well-established risk factor. J Natl Cancer Inst 1995;7:1681-5.

8 Pessaran Z, Rezaie A, Tavakolikia R, Siadat AH: Evaluation of breast cancer risk factors for using in hormone replacement therapy of corticosteroid-treated post-menopausal women. Journal of Shahrekord University of Medical Sciences 2003;2:70-5.

9 Khamechian T, Mazouchi T: Frequency of positive family history of breast cancer in 100 breast cance sufferers in Kashan. Feyz (Kashan University of Medical Sciences \& Health Services) 2004;28:90-4.

10 Kashfi F, Nikoofar AR, Mohammadi R: Fertility risk factors causing breast cancer. Medical Journal of Reproduction and Infertility 2002;9:38-45.
11 Vahdaninia MS, Harirchi AM, Montazeri A: Five-year survival in Iranian breast cancer patients: a prospective study. Payesh (Journal of The Iranian Institute For Health Sciences Research) 2003;2:141-8.

12 Al-Shaibani $\mathrm{H}, \mathrm{Bu}-A$ layyan S: Risk factors of breast cancer in Kuwait: case-control study. Iranian. Journal of Medical Sciences 2006;31:61-4.

13 Bhattacharya S, Adhikary S: Evaluation of risk factors, diagnosis and treatment in carcinoma breast - a retrospective study. Kathmandu Univ Med J (KUMJ) 2006;4:54-60.

14 Motamed N, Hadi N, Talei AR: A survey on risk factors of breast cancer in women over 35 years of age, Shiraz, 2000. Journal of Zanjan University of Medical Sciences \& Health services 2004;46:25-32.

15 Huo D, Adebamowo CA, Ogundiran TO, Akang EE, Campbell O, Adenipekun A, Cummings S, Fackenthal J, Ademuyiwa F, Ahsan H, Olopade OI: Parity and breastfeeding are protective against breast cancer in Nigerian women. Br J Cancer 2008;98:992-6.

16 Kruk J: Association of lifestyle and other risk factors with breast cancer according to menopausal status: a case-control study in the Region of Western Pomerania (Poland). Asian Pac J Cancer Prev 2007;8:513-24.

17 Velie EM, Nechuta S, Osuch JR: Lifetime reproductive and anthropometric risk factors for breast cancer in postmenopausal women. Breast Dis 2005-2006;24:17-35.

18 Naieni KH, Ardalan A, Mahmoodi M, Motevalian A, Yahyapoor Y, Yazdizadeh B: Risk factors of breast cancer in north of Iran: a case-control in Mazandaran Province. Asian Pac J Cancer Prev 2007;8:395-8.

19 Saeki T, Sano M, Komoike Y, Sonoo H, Honjyo H, Ochiai K, Kobayashi T, Aogi K, Sato N, Sawai S, Miyoshi Y, Takeuchi M, Takashima S: No increase of breast cancer incidence in Japanese women who received hormone replacement therapy: overview of a case-control study of breast cancer risk in Japan. Int J Clin Oncol 2008;13:8-11.
20 Yavari P, Mosavizadeh MA, Sadrol-Hefazi B, Khodabakhshi R, Madani H, Mehrabi Y: Reproductive characteristics and the risk of breast cancer: a case-control study. Iranian Journal of Epidemiology 2006;2:11-19.

21 Lord SJ, Bernstein L, Johnson KA, Malone KE, McDonald JA, Marchbanks PA, Simon MS, Strom BL, Press MF, Folger SG, Burkman RT, Deapen D, Spirtas R, Ursin G: Breast cancer risk and hormone receptor status in older women by parity, age of first birth, and breastfeeding: a casecontrol study. Cancer Epidemiol Biomarkers Prev 2008;17:1723-30.

22 Pourhoseingholi MA, Mehrabi Y, Alavi-Majd H, Yavari P, Safaee A: Association between risk of breast cancer and fertility factors - a latent variable approach. Asian Pac J Cancer Prev 2008;9:309-12.

23 Collaborative Group on Hormonal Factors in Breast Cancer: Breast cancer and breastfeeding: collaborative reanalysis of individual data from 47 epidemiological studies in 30 countries, including 50,302 women with breast cancer and 96,973 women without the disease. Lancet 2002;360:18795.

24 Lee E, Ma H, McKean-Cowdin R, Van Den Berg D, Bernstein L, Henderson BE, Ursin G: Effect of reproductive factors and oral contraceptives on breast cancer risk in BRCA1/2 mutation carriers and noncarriers: results from a populationbased study. Cancer Epidemiol Biomarkers Prey 2008; 17:3170-8.

5 Peterson NB, Huang Y, Newcomb PA, TitusErnstoff L, Trentham-Dietz A, Anic G, Egan KM: Childbearing recency and modifiers of premenopausal breast cancer risk. Cancer Epidemiol Biomarkers Prev 2008;17:3284-7.

26 Ebrahimi M, Vahdaninia MS, Montazeri A: Reproductive risk factors for breast cancer in Iran: a casecontrol study. Payesh (Journal of The Iranian Institute For Health Sciences Research) 2002;3:23-7.

27 Attar Parsaei F, Golchin M, Asvadi I: A study of relationship between demographics, life-style, stressful life-events and breast cancer in women. Medical Journal of Tabriz University of Medical Sciences \& Health Services 2001;50:15-21. 